Available online on 15.09.2020 at http://jddtonline.info
Open Access to Pharmaceutical and Medical Research
unrestricted non-commercial use, provided the original work is properly cited

Open $\odot$ Access

Research Article

\title{
Evaluation of Protein, Lipid and Inflammatory Profiles in Patients with Non- Hodgkin Lymphoma in the Western Region of Algeria
}

\author{
Meriem Rabia Zahzeh ${ }^{1 *}$, Touria Zahzeh1 \\ 1. Laboratory of Molecular Microbiology, Proteomics and Health, University of Sidi Bel Abbes, Algeria
}

\begin{abstract}
Introduction: Non-Hodgkin lymphoma (NHL) is part of the lympho-proliferative syndromes, it is a heterogeneous group of tumors whose incidence has been increasing in recent years. A disruption of protein and lipid profiles is verified during this pathology as well as an increase in the levels of specific markers of inflammation.

Objective: Our study aims to explore protein and lipid profiles and highlight an inflammatory syndrome via the assay of parameters of acute inflammation in patients with NHL and healthy subjects in western Algeria.

Methods: A case-control study comprising 100 patients with NHL and 40 healthy subjects was carried out. Protein and lipid profiles were respectively studied by assays for total protein and globulins and analysis of cholesterol and triglyceride levels. The inflammatory status was demonstrated by studying two parameters: $\mathrm{C}$ reactive protein (CRP) and sedimentation rate (VS).

Results: Our results demonstrated an increase in alpha1-globulin and a decrease in gamma-globulin in patients compared to controls ( $\mathrm{p}<0.05)$.

The lipid profile study showed no significant difference for cholesterol but a significant increase in triglycerides in patients with NHL ( $\mathrm{p}<0.05$ ). A highly significant difference in CRP and VS levels between our two groups $(p<0.01)$ with a marked increase in patients demo nstrated the presence of acute inflammatory syndrome.

Conclusion: This study allowed us to highlight the alterations in protein and lipid profiles found in NHL and the presence of an inflammatory state, involved in the pathophysiology of non-Hodgkin lymphoma in particular.

Keywords: non-Hodgkin lymphoma, protein profile, lipid profile, CRP, VS.
\end{abstract}

Article Info: Received 07 August 2020; Review Completed 11 August 2020; Accepted 16 August 2020; Available online 15 September 2020

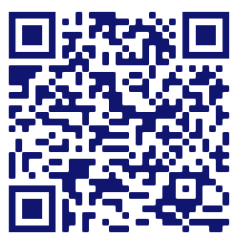

Cite this article as:

Zahzeh MR, Zahzeh T, Evaluation of Protein, Lipid and Inflammatory Profiles in Patients with Non-Hodgkin Lymphoma in the Western Region of Algeria, Journal of Drug Delivery and Therapeutics. 2020; 10(5):1-5

http://dx.doi.org/10.22270/jddt.v10i5.4335

Meriem Rabia Zahzeh, Laboratory of Molecular Microbiology, Proteomics and Health, University of Sidi Bel Abbes, Algeria

\section{INTRODUCTION}

Non-Hodgkin lymphoma (NHL) is a cancer of cells of the immune system, in fact it is defined by clonal proliferation of $\mathrm{B}$ and $\mathrm{T}$ lymphocytes at different stages of differentiation and activation. As the immune system is ubiquitous, any organ can be the starting point of lymphoma ${ }^{1,2}$.

In 2015, NHL was the most common malignant hemopathy ${ }^{3}$. The annual rate standardized to the world population is 6.7 per 100,000 inhabitants per year, with an increase of 10 to $20 \%$ every 5 years. It occurs at any age, with half of the cases observed in subjects over 60 years and a third in over 75 years, with a male predominance and a sex ratio equal to $1.5^{4}$.

In Algeria, more than 1,000 new cases are recorded each year, affecting $4 \%$ of the Algerian population. Extra-nodal non-Hodgkin lymphoma remains the most frequent with a histological prevalence of the large B-cell type, high grade and stage IV representing $60 \%$ of non-Hodgkin's lymphomas ${ }^{5}$.
The pathogenesis of NHL remains poorly understood, nevertheless several factors are involved including some viruses, immunosuppression, genetic and environmental factors such as pesticides and smoking6.

Variations in the value of total protein levels and of some proteins including albumin, alpha 1 and 2 globulins, beta and gamma globulins can be indicative of some pathologies, in particular NHL.

The detection of an inflammatory syndrome found during a cancerous process is based on the measurement of the sedimentation rate (VS), associated with the assay of the reactive $C$ protein which is a marker of choice among the proteins of the acute phase of inflammation 7, 8. Apart from inflammation, pathological variations in the CRP level are found in myocardial infarction, some cancers, immune diseases, chronic lymphoid leukemia, viral and bacterial infections and parasitic diseases ${ }^{9,10,11 .}$

A disruption of the lipid profile is observed in cancer patients, explained by the role of lipids in carcinogenesis, in fact, a positive correlation between the increase in 
cholesterol and triglyceride levels and a higher risk of developing cancers has been reported by several studies ${ }^{12,13}$, 14. In order to make a contribution to any screening and treatment action for NHL, we explored the protein, inflammatory and lipid profiles in 100 patients with this pathology in a hospital environment, and at the same time in 40 healthy subjects representing the control group in the western region of Algeria.

\section{MATERIALS AND METHODS}

\section{Subjects and methods}

100 patients with NHL (52 men, 48 women; age $55.79 \pm 1.48$ years) admitted to the Hematology departments of the hospital-university centers of Tlemcen and Sidi Bel Abbes western of Algeria and 40 healthy subjects (23 men, 17 women; age $56.36 \pm 3.01$ years) were the subject of this study.

A questionnaire with different characteristics was submitted to the subjects and the consent of the participants was validated by their signatures. This work was approved by our local institutional ethics committee (CSF-SBA).

\section{Blood samples}

The samples were taken from the antecubital vein and collected in dry tubes for the assays of total proteins, CRP, cholesterol and triglycerides and in EDTA tubes for the assay of VS.

\section{Laboratory assays}

\section{Determination of total protein}

The protein assay method is based on the work of Skeggs and Hochstrasser (1964). The reaction is triggered by adding the serum to the Biuret reagent. During the reaction, proteins in the sample combine with copper in an alkaline medium to form a purple colored complex. The absorption of the complex is measured at the end point at $550 \mathrm{~nm}^{15}$.

\section{Serum protein zone electrophoresis}

The HELENA method is based on the migration of serum proteins deposited on a "cellulose acetate" support subjected to an electric current according to their charge and their volume, the bands obtained form a proteinogram ${ }^{16}$.

\section{Reactive protein (CRP) assay}

The CRP-latex is a slide agglutination test for the qualitative and semi-quantitative detection of CRP in human serum. Latex particles coated with goat IgG anti-human CRP are agglutinated when mixed with samples containing CRP17.

\section{Determination of sedimentation rate (VS)}

It is a test that involves allowing red blood cells to settle in a vertical tube. The distance traveled is measured for 1 hour. The reference method is the Westergreen method 18 .

\section{Determination of cholesterol}

The method is based on the action of a cholesterol ester hydrolase enzyme which will hydrolyze esters of cholesterol into free cholesterol and fatty acid. Free cholesterol is oxidized by cholesterol oxidase to cholesterol $\mathrm{A}$ and hydrogen peroxide which oxidizes the chromogen in the presence of peroxidase giving a red compound. The reading is taken on a colorimeter at $520 \mathrm{~nm}^{19}$.

\section{Determination of triglycerides}

Triglycerides are hydrolyzed into glycerol and free fatty acid by lipoprotein lipase (LPL), glycerol kinase and ATP then convert glycerol into glycerol-3-phosphate (G3P) and adenosine diphosphate (ADP). The G3P is then converted into dihydroxy acetone (DAP) and hydrogen peroxide $\left(\mathrm{H}_{2} \mathrm{O}_{2}\right)$ by glycerol phosphate dehydrogenase (GPO). DAP reacts with 4-aminophenazone and p-chlorophenol in the presence of peroxidase giving a red color. The quinone concentration (pink) is measured at $505 \mathrm{~nm}$ and proportional to the level of triglycerides ${ }^{20,21}$.

\section{Statistical analyses}

Stratistic analyses were performed using SPSS 22.0 software. Student's t-test and Mann-Whitney $U$ test used as appropriate allowed us to compare the two groups. Data were presented as values \pm standard error of the mean. The $\mathrm{p}<0.05$ and $\mathrm{p}<0.01$ values were considered statistically significant and highly significant, respectively.

\section{RESULTS}

The characteristics of the patients and the controls are shown in Table I, no significant difference was observed between the two groups for age, sex and BMI ( $p>0.05$ ). B-cell NHL type was the most common (54\%) followed by T-cell NHL (23\%), with a predominance of stage I (35\%).

Table I: Characteristics of patients with NHL and controls

\begin{tabular}{|l|l|l|l|}
\hline Variables & Patients & controls & P \\
\hline Age (year) & $55,79 \pm 1,48$ & $56,36 \pm 3,01$ & 0,823 \\
\hline Sex (M/F) & $52 / 48$ & $23 / 17$ & 0,521 \\
\hline BMI (kg/m²) & $22,32 \pm 0,34$ & $22,36 \pm 0,63$ & 0,912 \\
\hline NHL type & & & - \\
B-cell NHL & 54 & - & - \\
T-cell NHL & 23 & - & - \\
Manteau & 8 & - & - \\
MALT & 13 & - & - \\
NK-cell NHL & 2 & - & \\
\hline Clinical stage & & & - \\
CS I (\%) & 35 & - & - \\
CS II (\%) & 25 & - & - \\
CS III (\%) & 17 & - & - \\
CS IV (\%) & 23 & - & \\
\hline
\end{tabular}

$p<0,05$ was considered statistically significant. Data are presented as mean \pm standard error. P: comparison between the two groups. BMI: body mass index, NHL: non Hodgkin lymphoma, CS: clinical stage. 
Figure I represents the protein profile of patients with NHL and controls, no significant difference was noted for total protein, alpha2 and beta-globulin. An increase in alpha1globulin and a decrease in gamma globulin were observed in patients compared to controls $(\mathrm{p}<0.05)$.

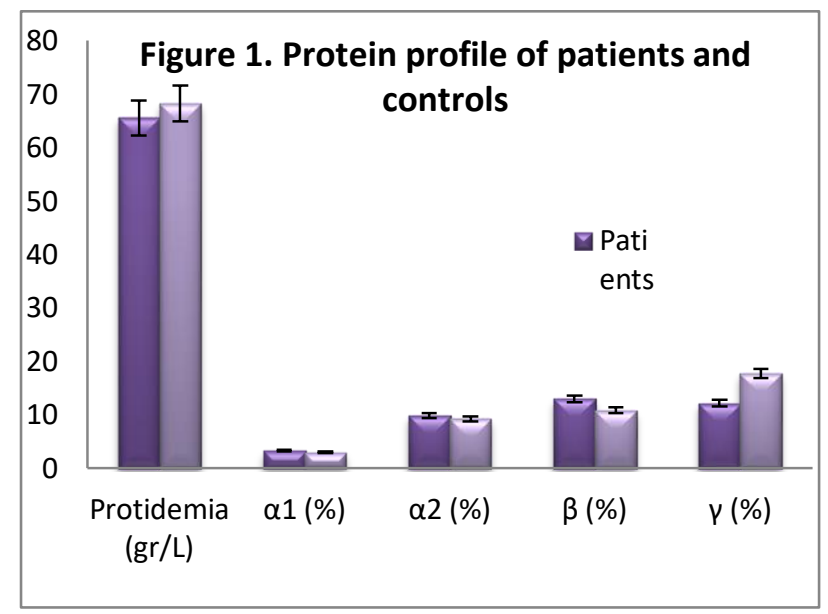

\section{profile of patients and controls}

Figure 1: Protein

Regarding the lipid profile summarized in Figure II, our results show no significant difference for cholesterol but a significant increase in triglycerides in patients compared to controls $(p<0.05)$.

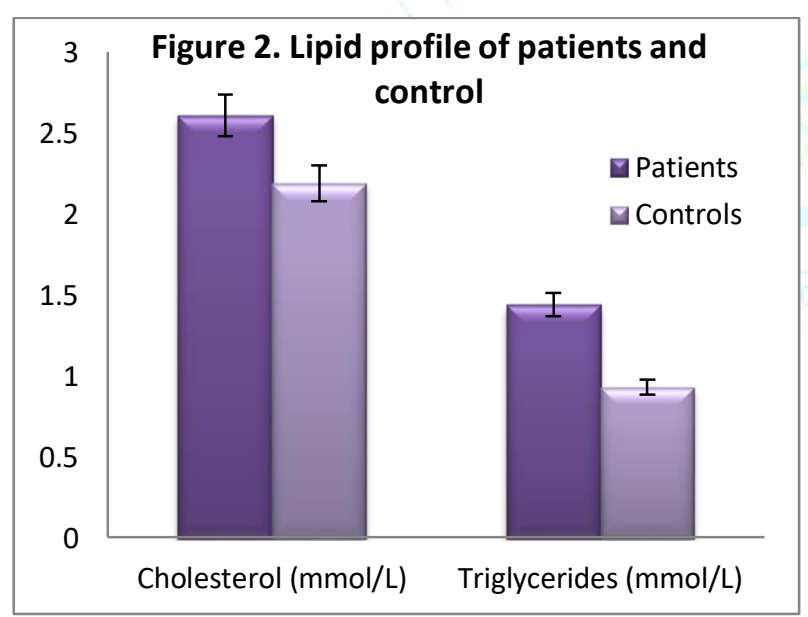

Figure 2: Lipid profile of patients and controls

The dosage of inflammatory markers (figure III) shows a very significant increase in CRP and VS in our patients ( $p$ $<0.01$ ).

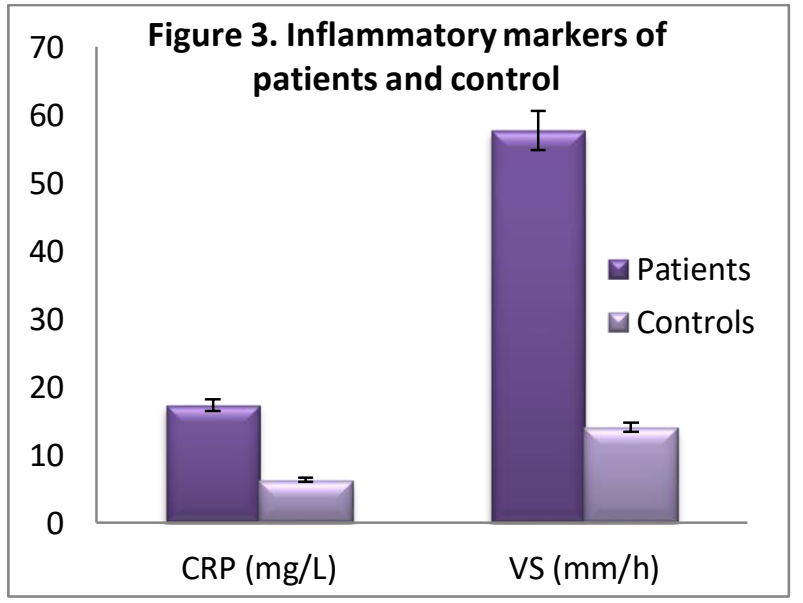

Figure 3: Inflammatory markers of patients and controls

\section{DISCUSSION}

NHL is distinguished by the variation in serum protein levels. Our results show a significant increase in alpha 1 globulin in patients, which corresponds to an inflammatory syndrome. Many multiprotein plasma activation systems playing the role of mediators intervene during inflammation, one can cite the contact system where there are 4 proteins including factor XI. Activated, this protein stimulates the production of bradykinin which triggers the production by endothelial cells of PGI2, thromboxane A2, tissue plasminogen activator causing pain, vasodilation, increased permeability vascular, and leukocyte margination. Alpha-1globulin will block this factor and therefore participate in the regulation of the inflammatory response. Our results agree with those of the literature and with the high level of CRP found during our assays ${ }^{22,23}$.

The gamma-globulin level, on the other hand, is markedly lower in the patients, with a significant difference between the two groups. The same observation was made by Balcells and by Gennes, who respectively associate hypogammaglobulinemia with a lymphoproliferative process and with lymphoid hemopathy24, 25. Thomas and Frenzel also note the decrease in this fraction during $\mathrm{NHL}^{26}$, 27.

The study of the inflammatory profile during our research has shown high levels for CRP and VS. The increase in CRP in patients with NHL is explained by the fact that neoplasias are pathologies with an inflammatory process. In fact, the tumor microenvironment, an essential player in the neoplastic process, promoting proliferation, survival and migration, is orchestrated by inflammatory cells. Inflammatory responses therefore play a decisive role at different stages of tumor development ${ }^{28}$. An increase in inflammatory cytokine levels observed during inflammation leads to the transcriptional induction of the CRP gene in hepatocytes of the liver ${ }^{29}$.

CRP binds to stimulatory receptors, Fc $\gamma R I$ and Fc $\gamma$ RIIa, increasing phagocytosis and the release of inflammatory cytokines and pro-apoptotic cytokines inducing up regulation of p53 in monocytes and affecting their cell cycle kinetics which leads to the apoptosis by G2 / M arrest in some cancer cell lines ${ }^{30}$. CRP also has the ability to induce phagocytosis of damaged cells 31,32 . It also binds to the inhibitory receptor, Fc $\gamma$ RIIb, blocking activation signals and playing an anti-inflammatory role $33,34,35$.

Moreover, this protein appears to be not only a peripheral biomarker of inflammation and allows a referral towards effective immunotherapies ${ }^{36}$, but also a useful and easy prognostic biomarker for NHL. The results of the study by Legouffe and al in 2009 indicate that $75 \%$ of patients with a CRP $<10 \mathrm{mg}$ / L survive 32 months after the diagnosis, while the group with a higher CRP level reaches a median survival of only 8.5 months ${ }^{37}$.

Regarding the sedimentation rate, the higher it is, the greater the probability of being confronted with a systemic inflammatory disease. The studies by Brigden and Monti published in 1998 and 2013 respectively come to the same conclusion; a VS> $100 \mathrm{~mm} /$ hour has a positive predictive value of $90 \%$ for severe infectious, rheumatic or neoplastic disease. In patients known to have oncologic disease, VS greater than $100 \mathrm{~mm} /$ hour is often associated with the presence of metastases, although normal VS does not exclude it ${ }^{38,39}$. In 2005, Durant et al also reported that tumor diseases are among the pathologies most frequently found during the exploration of an inflammatory syndrome 
objectified by an increase in VS 40 . These conclusions are consistent with our findings.

During carcinogenesis the lipid profile is also disturbed. Indeed, an induction of lipogenesis is essential for the proliferation of cancer cells ${ }^{41}$. The first tumor lipolytic factors (lipid mobilizing factor) were described in mice carrying lymphoma ${ }^{42}$

Lipids are important mediators of the immune response and inflammatory reactions ${ }^{43}$. Our results demonstrate significantly elevated triglyceride values in our subjects compared to the controls which could be explained on the one hand by a decrease in the catabolism of TG with an increase in their half-life due to the decrease in the activity of LPL and $\mathrm{LH}^{44}$ and on the other hand, by the fact that the environment of the tumor cell is characterized by an increase in the content of growth factors, which may be the cause of the over expression of the enzymes of lipogenesis in cancer cells. Alterations in the signaling pathways of these growth factors such as the MAPK pathway and the PI3K / AKT pathway are also responsible ${ }^{45,46 .}$

In addition, cancer cells are characterized by an increase in the expression of enzymes of lipogenesis inducing a high synthesis of lipids de novo (95\%) despite a sufficient food intake, on the contrary, under physiological conditions the intake of lipids comes from the diet while de novo synthesis remains low except in the liver and adipose tissue which regulate lipid homeostasis $47,48,49$.

\section{CONCLUSION}

In conclusion, the study of protein and lipid profiles, as well as the determination of markers of inflammation in patients with non-Hodgkin lymphoma and healthy subjects, first demonstrated a pathological variation of some serum proteins and increased triglycerides. In addition, it demonstrated, by the high levels of CRP and VS, the presence of an inflammatory state, both involved in the pathophysiology of cancers in general and of non-Hodgkin lymphoma in particular.

The unfavorable prognosis of patients and the problem of their therapeutic management could be linked to the alteration of protein and lipid metabolism but also to the chronic inflammation found during the neoplastic process.

\section{Conflict of interest}

The authors declare no conflicts of interest.

\section{REFERENCES}

1. Louanchi L, Allouda M, Ait Ameur N, et al, « Syndromes lymphoprolifératifs hors myélomes Aspects cliniques » Hématologie, 2015; 21(1):46-67.

2. Hordé $P$, "Lymphome (cancer du système lymphatique) symptômes et traitement », 2016; 206-218.

3. Boudjerra N, Oukid S, Abad MT and al, "Etude descriptive de 2915 cas de lymphomes non hodgkinien ganglionnaires de l'adulte. Période 2007-2012 » Revue algérienne d'hématologie, 2015; 10-11.

4. Ahossi V, Boisramé-Gastrin S, Perrot G, and al, «Non-hodgkinson lymphoma with mandibular localisation: two case histories» Med Buccale Chir Buccale, 2006; 12(1):21-29.

5. Zeggai S, Harir N, Touhami H, and al, « Profil histoépidémiologique des lymphomes des adultes dans l'Ouest algérien: à propos de 1544 cas» African Journal of Cancer, 2013; 5:127-132.

6. Moussati $S$ and Aina $M$, « Etude des facteurs associés au risque de lymphome malin non Hodgkinien ». Tlemcen, Algérie. 2016.

7. Dupuy AM, Badiou S, Descomps B and al, « Dosage immunoturbidimètrique de la CRP et de la CRP haute sensibilité sur sérum et plasma hépariné : apport des réactifs olympus » Spectra biologie, 2003; 132:44-46.
8. Evrard B, Roszyk L, Fattal S and al, « Evaluation de l'Actim CRP : test rapide de dosage semi- quantitatif de la CRP sur le sang total » Annales de biologie clinique, 2005; 5 .

9. Janeway CA, Travers P, Duverlie G and al. Immunobiologie. Paris : Masson ; 2003.

10. Bletry 0 , Khan JE and Somogyi A. Immunopathologie, réaction inflammatoire. Paris: Masson, 2006.

11. Boukhari AA, Hartani M, Boumesbah S, « Etude de la corrélation entre la vitesse de sédimentation et la protéine $C$ réactive dans la recherche de syndrome inflammatoire » Hématologie, 2019.

12. Kuzu OF, Noory MA and Robertson GP, «The Role of Cholesterol in Cancer» Cancer research. 2016; 76(8):2063-2070.

13. Ding $X$, Zhang W, Li S, and al, «The Role of Cholesterol Metabolism in Cancer» Suis J Cancer Res, 2019; 9(2):219-227.

15. Allioua M. «Statut nutritionnel et désordres métaboliques chez les patients atteints de lymphome non hodgkinien ». Tlemcen, Algérie, 2011.

15. Skeggs LT Jr and Hochtrasser $\mathrm{H}$, «Multiple automatic sequential analyses» Clin Chem, 1964.

16. Aribi M, «Eléctrophorèses de zone des proteines sériques sur acétate de cellulose : méthode densitométrique (HELENA) ». Tlemcen, Algérie, 2007.

17. Anonyme, « CRP-Latex, slide agglutination ». Spain : Spinreact S.A, 2005.

18. Borghini T, Vernez L, Kesseler D, « Fiche technique protéine $C$ réactive et vitesse de sédimentation». Centre suisse de contrôle de qualité, 2013.

19. Natio HK, « Cholesterol » Clin Chem The C.V. Mosby Co. St Louis. Toronto. Princeton, 1984; 1194-11206.

20. Fossati $P$ and Prencipe L, «Serum triglycerides determined colorimetrically with an enzyme that produces hydrogen peroxide» Clin Chem, 1982; 28:2077-80.

21. Kaplan A and al, «Triglycerides» Clin Chem the C.V. Mosby Co. St Louis. Toronto. Priceton, 1984; 1194-1206.

22. Boussarie D. L'électrophorèse des protéines sériques en pathologie du furet (Mustela putorius furo). France : Bull. Acad. Vét; 2007.

23. Bouayadi O, Bensalah $\mathrm{M}$, Rahmani $\mathrm{N}$ and al, «Electrophorèse des protéines sériques: étude de 410 profils électrophorétiques» Pan Afr Med J, 2019; 32:161.

24. Gennes C. Syndromes inflammatoires. Traité de médecine interne. Flammarion ; 1996. P. 98-102.

25. Balcells A. Examen de laboratoire pour le praticien. Paris : Masson ; 1998.

26. Thomas C. Interprétation de l'électrophorèse des protéines sériques. F.M.C Tourcoing, 2015.

27. Frenzel L, « L'hypogammaglobulonémie : que faut-il en retenir ? » Feuillets de biologie, 2017.

28. Grivennikov SI, Greten FR, Karin M, «Immunity, Inflammation, and Cancer »Cell, 2010; 140(6):883-99.

29. Boras E, Slevin M, Alexander MY and al, «Monomeric C-reactive protein and Notch-3 co-operatively increase angiogenesis through PI3K signalling pathway» Cytokine, 2014; 69:165-79.

30. Guyton KZ, Xu Q, Holbrook NJ, «Induction of the mammalian stress response gene GADD153 by oxidative stress: role of AP-1 element» Biochem J, 1996; 314(2):547-54.

31. Kim Y, Ryu J, Ryu MS and al, «C-reactive protein induces G2/M phase cell cycle arrest and apoptosis in monocytes through the upregulation of B-cell translocation gene 2 expression» FEBS Lett, 2014; 588(4):625-31.

32. Tugal D, Liao X, Jain MK, «TIS21 (/BTG2/PC3) as a link between ageing and cancer: cell cycle regulator and endogenous cell death molecule» Arterioscler Thromb Vasc Biol, 2013; 33:113544.

33. Marnella L, Moldb C, Du Clos TW, « C-reactive protein: Ligands, receptors and role in inflammation» Clinical Immunology, 2005; 117(2):104-111.

34. Devaraj S, Du Clos TW, Jialal I, « Binding and internalization of Creactive protein by Fcgamma receptors on human aortic endothelial cells mediates biological effects» Arterioscler Thromb Vasc Biol, 2005; 26:1359-63.

35. Sproston NR and Ashworth JJ, « Rôle de la protéine C-réactive sur les sites d'inflammation et d'infection » Front Immunol, 2018; 9: 754 .

36. Felger JC, Haroon E, Patel TA and al, «What does plasma CRP tell us about peripheral and central inflammation in depression?» Molecular Psychiatry, 2020; 25:1301-1311. 
37. Legouffe E, Rodriguez C, Picgt $\mathrm{MC}$ and al, «C-Reactive Protein Serum Level is a Valuable and Simple Prognostic Marker in Non Hodgkin's Lymphoma» Leukemia \& Lymphoma, 1998; 31:34:351-357.

38. Brigden $M$, «The erythrocyte sedimentation rate. Still a helpful test when used judiciously» Postgrad Med, 1998; 103.

39. Monti M, «Vieux et nouveaux biomarqueurs inflammatoires : quelle utilité pour l'interniste généraliste ? » Rev Med Suisse, 2013; 9:2008-2012.

40. Durant R, Blain H, Jeandel C, « Syndrome inflammatoire chez la personne âgée » Traité EMC AKOS (Traité de Médecine), 2005.

41. Pierre AS. Le métabolisme des acides gras monoinsaturés et la prolifération des cellules cancéreuses coliques : rôle de la Stéaroyl-CoA Désaturase-1 et effets des isomères conjugués de l'acide linoléique. Université de Bourgogne; 2012.

42. Raynard B, Barnoud D, Schneider SM and al. Nutrition et hémopathies malignes. Traité de nutrition artificielle de l'adulte. La société francophone de nutrition entérale et parentérale ; 2007. P.777-785.

43. Lagarde L, "Métabolisme des lipides bio-actifs. Pathologie Biologie » Edition scientifique et medicals Elsevier SAS, 2003; 51:241-243.
44. Weinroth SE, Parenti DM, Simon GL, «Wasting syndrome in AIDS: pathophysiologic mechanisms and therapeutic approaches» Infect Agents Dis, 1995; 4:76-94.

45. Swinnen JV, Vanderhoydonc F, Elgamal AA and al, « Selective activation of the fatty acid synthesis pathway in human prostate cancer» Int J Cancer, 2000; 88:176-179.

46. Yoon S, Lee MY, Park SW and al, « Up-regulation of acetyl-CoA carboxylase alpha and fatty acid synthase by human epidermal growth factor receptor 2 at the translational level in breast cancer cells» J Biol Chem, 2007; 282:26122-26131.

47. Swinnen JV, Brusselmans K, Verhoeven G, « Increased lipogenesis in cancer cells: new players, novel targets» Curr Opin Clin Nutr Metab Care, 2006; 9:358-365.

48. Sakai K, Okuyama H, Yura J and al, « Composition and turnover of phospholipids and neutral lipids in human breast cancer and reference tissues» Carcinogenesis, 1992; 13:579-584.

49. Robert J, Montaudon D, Hugues P, « Incorporation and metabolism of exogenous fatty acids by cultured normal and tumoral glial cells» Biochim Biophys Acta, 1983; 752:383-395. 